\title{
NEM SCHEMES ANALYSIS BASED ON INSTALLED GRID-CONNECTED PV SYSTEM FOR RESIDENTIAL SECTOR IN MALAYSIA
}

\author{
W. M. W. MUDA ${ }^{1,2}$, N. ANANG ${ }^{2}$ \& AIDY M. MUSLIM ${ }^{3}$ \\ ${ }^{1}$ Renewable Energy and Power Research Interest Group (REPRIG), Eastern Corridor Renewable Energy SIG. \\ ${ }^{2}$ Faculty of Ocean Engineering Technology and Informatics, Universiti Malaysia Terengganu, \\ 21030 Kuala Nerus, Terengganu, Malaysia. \\ ${ }^{3}$ Institute of Oceanography and Environment (INOS), Universiti Malaysia Terengganu, \\ 21030 Kuala Nerus, Terengganu, Malaysia.
}

\begin{abstract}
An investigation has been conducted to analyse the performance of a grid-connected photovoltaic system (GCPV) based on the net energy metering (NEM) scheme. Several analyses of a similar system have been performed in the literature based on assumptions and simulations. However, the concept based on actual NEM data in Malaysia has not been fully considered. Hence, this study analyses the real performance of the GCPV system from the field monitoring of PV energy production, as well as import and export energy, collected at a residential house participating in NEM 2.0. From the collected data, the economic parameters were calculated and compared with an equivalent system before the NEM implementation, which is a grid-only system, and the NEM 1.0 and 3.0 schemes. The results show that for the considered load demand with an average monthly electricity bill of RM 500, the NEM 2.0 provides more benefits to consumers with the lowest payback period, net present cost, net saving and energy cost. Although NEM 3.0 produced the lowest net saving, which was RM 33,280 for 20 years of the project's lifetime, it was still capable of reducing the electricity bill by $66 \%$ for the first year and $32 \%$ during self-consumption.

Keywords: economic analysis, grid-connected PV system, Kuala Terengganu, net energy metering.
\end{abstract}

\section{INTRODUCTION}

The net energy metering (NEM) concept was launched in the 1980s in the United States to reduce dependency on the conventional grid, to promote green energy technology and to encourage on-site distributed generation, especially from rooftop solar panels and smallscale renewable energy (RE) sources [1]. The main benefit of the NEM is to reduce the monthly electricity bill by consuming the energy produced by the RE system. Any shortage of electricity is backed up by importing the energy from the grid, and an excess of electricity is exported back into the grid. The net meter calculates the net energy used by the consumer at the end of the month. In most cases, residential NEM consumes more power than RE production; thus, consumers still have to pay a small amount of electricity bill [1].

Several studies have been conducted in the literature to analyse the performance of PV systems under the NEM scheme in Malaysia [2-5], especially for residential areas. Authors in [4] compared Feed-in-Tariff (FiT) and NEM schemes in terms of the payback period for low- and medium-load consumption. Since the FiT rate was assumed to decrease by $8 \%$ every year until the period ended, there were cases where the payback period of the FiT scheme was higher than that of the NEM. In reality, the FiT rate is fixed for 21 years once the commencement date has been achieved [6]. The rate decreases every year due to the decrease in RE technology market price, but this is only applicable to new Feed-in-Approval Holder (FiAH). Mansur et al. [5] investigated the technical, economic and environmental aspects. The considered load profile was low, and the authors varied the size of the capacity from 2 to $12 \mathrm{kWp}$. It is true that for low-load demand and high PV capacity, there is a possibility that 
customers do not have to pay for their electricity bill as it reaches zero. Nonetheless, the higher the PV capacity, the higher the installation costs and maintenance costs, which were not considered in their study. Thus, the longer the payback period, the longer the customers have to endure due to low savings. Razali et al. [2] proposed integration of time of use (TOU) into the NEM scheme to improve the original NEM. However, the highlighted problem of NEM was not accurate by comparing low- and high-load profiles using the same capacity of the PV system. In reality, the low-load profile should be installed with a low PV capacity so it will yield the same benefit as the high-load profile with a high PV capacity. Razali et al. [7] compared NEM 1.0 and NEM 2.0 using three different sizes of customers and PV capacity of $1-8 \mathrm{kWp}$. The period of simulation is 25 years. However, the calculated bill equations for NEM 2.0 were not correctly written. In their paper, the net power from the net meter was calculated before being multiplied with the price tariff. The actual calculation should be that the imported energy is multiplied with the gazette tariff, and the export bill is calculated by multiplying the exported energy with the gazette tariff in descending order [8]. Thus, this misconception affected the results obtained. In addition, the authors of [3] calculated the PV production from PV-rated power. Nevertheless, from the literature [9], the annual capacity factor, which is the ratio of the actual annual energy output to the amount of energy that the system would produce at full-rated power, shows that the value is low, around $20 \%$. Hence, it is not accurate if the full-rated power is used in the calculation to find the payback period, as it is far from being true.

From the above-mentioned literature, it is obvious that all these misconceptions were due to unclear explanations on authorities' websites, such as the Sustainable Energy Development Authority (SEDA) Malaysia [6]. In addition, previous research was based on simulations and assumptions. The novelty of this research work is the performance of the PV system assessed based on real data collection from field monitoring of a residential house participating in NEM 2.0. In addition, the correct way to calculate the actual monthly electricity bill for NEM 2.0 is shown. From the collected data, the economic parameters of NEM 2.0 are calculated and compared with the grid-only system. Then, using the same data, the economic parameters for NEM 1.0 and NEM 3.0 are computed for comparison purposes.

\section{NET ENERGY METERING}

NEM is one of the renewable energy policies to encourage consumers to produce their own electricity. It is also known in the literature as net metering, or net FiT [10]. The main difference between net FiT and gross FiT is the amount of electricity fed into the grid. If all the electricity generated is fed into the grid and the consumers purchase any electricity to consume from the grid, then it is gross FiT. Meanwhile, in the NEM or the net FiT scheme, only the excess electricity is exported into the grid. In both schemes, the electricity producers are paid at a certain rate for any injected electricity into the grid.

The export rate is different for different countries, and it depends on many factors. In certain countries, the export rate depends on the capacity of the plant, types of RE sources and different sectors [11]. The authors of [3] and [7] have listed export rates for different countries, such as Australia, Canada, Cyprus, Greece and the Netherlands. Table 1 shows additional countries with different import and export rates.

There is also literature research on finding the best export rate to increase electricity producers from RE, such as in [15] and [16]. In Malaysia, the export rate is different based on different schemes. For the gross FiT scheme that was introduced in 2011, the export rate was so high compared to the import rate that it boosted the RE producers among consumers from 649 MW in 2012 [17] to 2,072 MW in 2017 [18]. Although the FiT rate has decreased every 
Tabe 1: Comparison of import and export rates for different countries.

\begin{tabular}{lll}
\hline Country & Export rate & Electricity tariff \\
\hline France [12] & $0.05 € / \mathrm{kwh}=0.24 \mathrm{RM} / \mathrm{kWh}$ & $0.08 € / \mathrm{kwh}=0.39 \mathrm{RM} / \mathrm{kWh}$ \\
India [11] & Rs. $15 / \mathrm{kwh}=1.23 \mathrm{RM} / \mathrm{kWh}$ & Rs. $4 / \mathrm{kWh}=0.33 \mathrm{RM} / \mathrm{kWh}$ \\
Iran [13] & $0.08 \$ / \mathrm{kWh}=0.33 \mathrm{RM} / \mathrm{kWh}$ & $0.05 \$ / \mathrm{kWh}=0.21 \mathrm{RM} / \mathrm{kWh}$ \\
Spain [14] & 0 & $0.2477 € / \mathrm{kWh}=1.21 \mathrm{RM} / \mathrm{kWh}$ \\
\hline
\end{tabular}

Table 2: Domestic tariff rate [19].

\begin{tabular}{lllll}
\hline $\mathbf{R}_{\mathbf{i}}$ & Block tariff & Rate $(\mathbf{R M} / \mathbf{k W h})$ & Service tax & RE fund \\
\hline $\mathrm{R}_{1}$ & 200 & 0.218 & & \\
$\mathrm{R}_{2}$ & 100 & 0.334 & $0 \%$ & $1.6 \%$ \\
$\mathrm{R}_{3}$ & 300 & 0.516 & & \\
$\mathrm{R}_{4}$ & 300 & 0.546 & $6 \%$ & \\
$\mathrm{R}_{5}$ & $>900$ & 0.571 & & \\
\hline
\end{tabular}

year due to the decrease in RE technologies, it has received encouraging responses from Malaysians, especially in the residential sector, which has seen the highest percentage of FiT applications at $85.85 \%$ in the SEDA Annual Report 2017 [18]. To reduce the burden of the government paying a high FiT rate, the NEM scheme has been implemented in Malaysia since 2016.

\subsection{NEM 1.0}

The NEM concept was introduced in Malaysia not only to reduce dependency on imported fossil fuels but also to reduce monthly electricity bills if there is any possibility of future increase in electricity tariffs. The NEM is executed by the Ministry of Energy and Natural Resources (KeTSA), regulated by the Energy Commission (EC), with the SEDA Malaysia as the implementing agency.

The government offers a 500 MW quota for the PV system under this scheme. In NEM 1.0, every exported energy unit into the grid will be credited in the next billing at a displaced cost of $0.31 \mathrm{RM} / \mathrm{kWh}$ unit.

As shown in Table 2, the electricity purchase rate in Malaysia is based on a different block. The higher the load consumption, the higher the rate. From the table, it can be seen that the $6 \%$ service tax is not applied to the first $600 \mathrm{kWh}$ and $1.6 \%$ is applied to the total cost of electricity used as the RE fund collected by the government to promote the growth of electricity generation from RE.

Thus, NEM 1.0 is beneficial for low-load consumption, especially if it is lower than 200 units, as the purchase rate is lower than the sellback rate. However, for high-load consumption, a high tariff rate is applied, so it is not financially appealing.

The low performance of NEM 1.0 can be seen from the SEDA annual report 2018 [20], where only $5.6 \%$ of the $500 \mathrm{MW}$ quota has been approved. In the same report, the new concept was introduced in NEM 2.0. 


\subsection{NEM 2.0}

To overcome the disadvantages of NEM 1.0, the government of Malaysia has improvised the concept of NEM 2.0, starting on 2nd January 2019. This scheme is only applicable to Peninsular Malaysia consumers who registered with Tenaga Nasional Berhad (TNB), where the export bill is calculated using the same tariff as in Table 2, but in reverse order. Thus, for higher load consumption, a higher rate will be applied to the export bill. Due to this improvement, the quota of $500 \mathrm{MW}$ was discontinued 1 month before the end date of $31 \mathrm{st}$ December 2020. Similar to NEM 1.0, any excess electricity can be rolled over for a maximum period of 24 months. After that period, the excess energy will be forfeited. The offset period of this scheme is also 20 years, as in the previous scheme.

\subsection{NEM 3.0}

Starting on 1st February 2021, the government has offered another 200 MW of capacity from solar systems under NEM 3.0. This quota is further divided into two, which are $100 \mathrm{MW}$ under NEM Rakyat (residential building) and another $100 \mathrm{MW}$ under NEM GoMEn (government building). Another $300 \mathrm{MW}$ is reserved to be offered on 1st April 2021 for NOVA, which is for commercial and industrial sectors. This quota is open for 3 years. The biggest change in this scheme is the offset period, which is only 10 years. It means, for the first 10 years, the concept is similar to NEM 2.0, where the excess electricity is exported into the grid and will be credited on the next bill at a retail rate in reverse order.

After 10 years, the system uses the self-consumption (SELCO) concept. During SELCO, the excess electricity can be exported into the grid, but no export bill is considered. Thus, the consumer is encouraged to fully utilise PV production. The second change is that the rollover period is reduced to 12 months, and there is no rollover during the SELCO. To enhance the self-consumption of rooftop solar PV prosumers, there is a necessity to incorporate a battery energy storage system into the solar system [16].

\section{METHODOLOGY}

In this study, the performance of the installed grid-connected PV (GCPV) system of a house with a NEM 2.0 scheme was investigated. The specification of the PV system is summarised in Table 3.

From 2 meters provided during the installation of the system, three types of data were collected, namely the PV production $\left(E_{P V}\right)$, energy import $\left(E_{\text {import }}\right)$ and export $\left(E_{\text {export }}\right)$. Daily values of these data are available to the owner of the house. The monthly data for these parameters for the year 2020 are shown in Fig. 1. From these data, PV energy self-consumed $\left(E_{p v, \text { selco }}\right)$ and total energy used by the load $\left(E_{\text {load }}\right)$ can be calculated from eqns (1) and (2), respectively.

$$
\begin{aligned}
& E_{p v, \text { selco }}=E_{P V}-E_{\text {export }} \\
& E_{\text {load }}=E_{\text {import }}-E_{p v, \text { selco }}
\end{aligned}
$$

Total energy consumption by the load and the grid can be written as in eqn (3), and the total energy production by PV and the conventional grid is given in eqn (4).

$$
\text { Total consumption }(k W h)=E_{\text {load }}+E_{\text {export }}
$$


Table 3: Specification of installed PV system.

\begin{tabular}{ll}
\hline Parameters & Values \\
\hline Total PV capacity & $6.12 \mathrm{kWp}$ \\
1 unit PV capacity & $340 \mathrm{~W}$ \\
Number of PV module & 18 units \\
PV lifetime & 21 years \\
Roof covered area & $36 \mathrm{~m}^{2}$ \\
Inverter capacity & 1 unit $6 \mathrm{~kW}$ \\
Inverter lifetime & $10-15$ years \\
Project lifetime & 20 years \\
Capital cost & RM 26,592.00 \\
\hline
\end{tabular}

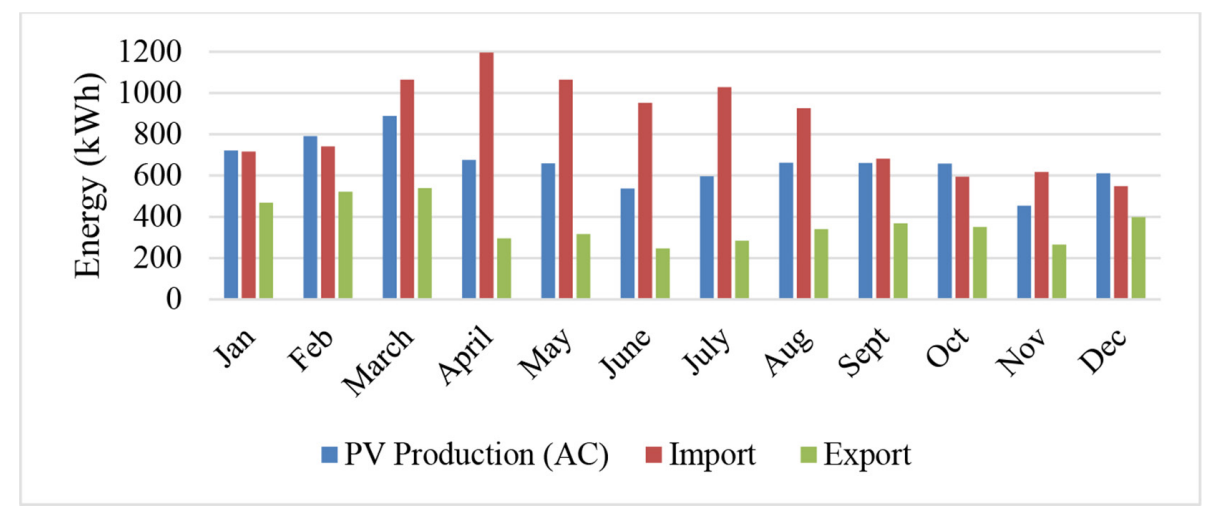

Figure 1: PV production, import and export energy collected for the year 2020.

$$
\text { Total production }(k W h)=E_{P V}+E_{\text {import }} \text {. }
$$

From $E_{\text {load }}$, the electricity bill before the PV system was installed (Bill beforeNEM $_{\text {in }}$ can be estimated from a standard calculation using the electricity tariff as in Table 2. The monthly savings can be obtained from the collected data based on eqn (5).

$$
\text { Saving }=\text { Bill }_{\text {beforeNEM }}-\text { Bill }_{\text {afterNEM }} \text {. }
$$

Then, a simple payback period $(P B)$ that shows the shortest period for the cumulative economic savings to become equal to the total initial investment can be computed [9] using the following equation:

$$
P B=\frac{\text { Capital cost }}{\text { saving }}
$$

The saving in eqn (5) is not a net savings, but based on monthly savings obtained from electricity bill reduction. The more accurate way to calculate the savings is by considering all 
costs during the project's lifetime as a net present cost (NPC). The NPC value considers all costs during the project's lifetime, including the capital cost, maintenance and operation costs $(\mathrm{O} \& \mathrm{M})$, replacement costs, salvage and grid sales revenue. Neglecting the annual real discount rate, the NPC can be calculated using the following equation.

$$
N P C(R M)=\text { Total expenditure }(R M)-\text { Total revenue }(R M) \text {. }
$$

Another important parameter is the cost of energy $(C O E)$, which shows how much the consumer has to spend per kWh.

$$
\operatorname{COE}\left(\frac{R M}{k W h}\right)=\left(\frac{\text { Annualized total cost }(R M)}{\text { Total consumption }(k W h)}\right)
$$

where the total consumption is given in eqn (3) and annualised total cost can be obtained from the $N P C$ value. The annual net savings can then be obtained from the following equation:

$$
\text { Saving }_{\text {net }}(R M)=\frac{N P C_{\text {beforeNEM }}-N P C_{\text {afterNEM }}}{\text { Project lifetime }}
$$

\section{RESULTS AND DISCUSSION}

This section is divided into four parts. First, the economic analysis before installing the PV system is presented. Next, based on the actual NEM 2.0 electricity bill, the correct way to calculate the export bill is presented. Then, the performance of NEM 2.0 is discussed based on data collection. The comparison between all three NEMs is elaborated in the last subsection. All results were obtained by calculation based on a year's data collection. The assumption was made that all collected data would remain for 20 years.

\subsection{Grid-only system}

Before analysing the impact of the NEM system, first, the economic parameters using a gridonly system were analysed. For the annual energy consumption, $\boldsymbol{E}_{\text {load }}$ was calculated from eqn (2), which was $13,654 \mathrm{kWh}$. Then, the annual electricity bill before NEM had been implemented was calculated using Table 2, showing a value of RM 6,701/year. The NPC of this system for 20 years was obtained by multiplying the annual bill before NEM by 20 years, neglecting the initial cost incurred by the consumer during the installation of the grid connection. Assuming the bill remains for 20 years, the $\boldsymbol{N P C}_{\text {beforeNEM }}$ would be RM 134,020. From the annual bill and energy consumption, the $\boldsymbol{C O E}_{\text {before } N E \boldsymbol{M}}$ was obtained, showing a value of $0.4908 \mathrm{RM} / \mathrm{kWh}$.

\subsection{Export bill calculation}

This section shows how the NEM 2.0 electricity bill was calculated. It depends on $\boldsymbol{E}_{\text {import }}$ and $\boldsymbol{E}_{\text {export }}$ First, the import bill was calculated similar to a standard electricity bill using Table 2. To encourage RE producers to use the NEM scheme, the government calculates the export bill in reverse order starting with the higher block tariff, subjected to the maximum block tariff used in the import bill. 
Two examples are given here based on the actual bill. From Fig. 1, the electricity bills in April and December were taken as examples, where in April, $\boldsymbol{E}_{\text {import }}$ was the highest at 1,196 kWh but $\boldsymbol{E}_{\text {export }}$ was low, while in December, $\boldsymbol{E}_{\text {import }}$ was $548 \mathrm{kWh}$ and $\boldsymbol{E}_{\text {export }}$ was $398 \mathrm{kWh}$. The electricity bill before tax in April 2020 is presented in Table 4. Since the highest rate for the import bill was $\mathrm{R}_{5}$, the export bill was calculated starting from that rate. The total exported energy in April was only $295 \mathrm{kWh}$, which was less than the amount of imported energy at $\mathrm{R}_{5}$. Hence, the total export energy was multiplied by that rate.

In December 2020, the import bill was calculated, as shown in Table 5. Since the imported energy was low, the maximum rate was $R_{3}$. Thus, $R_{3}$ was the highest rate used in the calculation of the export bill in December. Since the $\boldsymbol{E}_{\text {import }}$ for the $\mathrm{R}_{3}$ was only $248 \mathrm{kWh}$ and the total $\boldsymbol{E}_{\text {export }}$ was higher than that, the balance of usage was multiplied with the lower rate of $\mathrm{R}_{2}$. Since the maximum usage block of $\mathrm{R}_{2}$ was $100 \mathrm{kWh}$, the remaining $50 \mathrm{kWh}$ was multiplied with the lowest rate of $\mathrm{R}_{1}$.

In general, the relationship between import and export bills is represented in Table 6. Fifteen different cases may occur. For example, in reference to case 1, if the import bill is high and extends up to $R_{5}$, the export bill will start at $R_{5}$ with the same number of electricity units or less, depending on the value of exported energy. If the exported energy is high, it extends the rate up to $R_{1}$.

To prevent the rollover of excess energy to the next billing statement, the exported energy must always be less than or equal to the imported energy. Consequently, NEM customers

Table 4: Calculation of import and export bill in April 2020.

\begin{tabular}{|c|c|c|c|c|c|c|c|}
\hline \multicolumn{4}{|c|}{ Import bill } & \multicolumn{4}{|c|}{ Export bill } \\
\hline $\mathbf{R}_{\mathbf{i}}$ & $\begin{array}{l}\text { Rate (RM/ } \\
\text { kWh) }\end{array}$ & $\begin{array}{l}\text { Usage } \\
(\mathbf{k W h})\end{array}$ & $\begin{array}{l}\text { Amount } \\
(\mathrm{RM})\end{array}$ & $\mathbf{R}_{\mathbf{i}}$ & $\begin{array}{l}\text { Rate (RM/ } \\
\text { kWh) }\end{array}$ & $\begin{array}{l}\text { Usage } \\
(\mathbf{k W h})\end{array}$ & $\begin{array}{l}\text { Amount } \\
(\mathrm{RM})\end{array}$ \\
\hline $\mathrm{R}_{1}$ & 0.218 & 200 & 43.60 & $\mathrm{R}_{5}$ & 0.571 & 295 & 168.45 \\
\hline $\mathrm{R}_{2}$ & 0.334 & 100 & 33.40 & $\mathrm{R}_{4}$ & 0.546 & 0 & 0.00 \\
\hline $\mathrm{R}_{3}$ & 0.516 & 300 & 154.80 & $\mathrm{R}_{3}$ & 0.516 & 0 & 0.00 \\
\hline $\mathrm{R}_{4}$ & 0.546 & 300 & 163.80 & $\mathrm{R}_{2}$ & 0.334 & 0 & 0.00 \\
\hline $\mathrm{R}_{5}$ & 0.571 & 296 & 169.02 & $\mathrm{R}_{1}$ & 0.218 & 0 & 0.00 \\
\hline Total & & 1,196 & 564.62 & Total & & 295 & 168.45 \\
\hline
\end{tabular}

Table 5: Calculation of import and export bill in December 2020.

\begin{tabular}{|c|c|c|c|c|c|c|c|}
\hline \multicolumn{4}{|c|}{ Import bill } & \multicolumn{4}{|c|}{ Export bill } \\
\hline $\mathbf{R}_{\mathrm{i}}$ & $\begin{array}{l}\text { Rate (RM/ } \\
\text { kWh) }\end{array}$ & $\begin{array}{l}\text { Usage } \\
(\mathrm{kWh})\end{array}$ & $\begin{array}{l}\text { Amount } \\
(\mathrm{RM})\end{array}$ & $\mathbf{R}_{\mathbf{i}}$ & $\begin{array}{l}\text { Rate (RM/ } \\
\text { kWh) }\end{array}$ & $\begin{array}{l}\text { Usage } \\
(\mathrm{kWh})\end{array}$ & $\begin{array}{l}\text { Amount } \\
\text { (RM) }\end{array}$ \\
\hline $\mathrm{R}_{1}$ & 0.218 & 200 & 43.60 & $\mathrm{R}_{3}$ & 0.516 & 248 & 127.97 \\
\hline $\mathrm{R}_{2}$ & 0.334 & 100 & 33.40 & $\mathrm{R}_{2}$ & 0.334 & 100 & 33.40 \\
\hline $\mathrm{R}_{3}$ & 0.516 & 248 & 127.97 & $\mathrm{R}_{1}$ & 0.218 & 50 & 10.90 \\
\hline Tot & & 548 & 204.97 & Total & & 398 & 172.27 \\
\hline
\end{tabular}


Table 6: Fifteen different cases in import and export bills of NEM.

\begin{tabular}{llllll|lllll}
\hline \multicolumn{7}{c|}{ Import bill } & \multicolumn{7}{c}{ Export bill } \\
\hline Case & $\mathbf{R}_{\mathbf{1}}$ & $\mathbf{R}_{\mathbf{2}}$ & $\mathbf{R}_{\mathbf{3}}$ & $\mathbf{R}_{\mathbf{4}}$ & $\mathbf{R}_{\mathbf{5}}$ & $\mathbf{R}_{\mathbf{5}}$ & $\mathbf{R 4}$ & $\mathbf{R}_{\mathbf{3}}$ & $\mathbf{R}_{\mathbf{2}}$ & $\mathbf{R}_{\mathbf{1}}$ \\
\hline 1 & $\sqrt{ }$ & $\sqrt{ }$ & $\sqrt{ }$ & $\sqrt{ }$ & $\sqrt{ }$ & $\sqrt{ }$ & $\sqrt{ }$ & $\sqrt{ }$ & $\sqrt{ }$ & $\sqrt{ }$ \\
2 & $\sqrt{ }$ & $\sqrt{ }$ & $\sqrt{ }$ & $\sqrt{ }$ & $\sqrt{ }$ & $\sqrt{ }$ & $\sqrt{ }$ & $\sqrt{ }$ & $\sqrt{ }$ & \\
3 & $\sqrt{ }$ & $\sqrt{ }$ & $\sqrt{ }$ & $\sqrt{ }$ & $\sqrt{ }$ & $\sqrt{ }$ & $\sqrt{ }$ & $\sqrt{ }$ & & \\
4 & $\sqrt{ }$ & $\sqrt{ }$ & $\sqrt{ }$ & $\sqrt{ }$ & $\sqrt{ }$ & $\sqrt{ }$ & $\sqrt{ }$ & & & \\
5 & $\sqrt{ }$ & $\sqrt{ }$ & $\sqrt{ }$ & $\sqrt{ }$ & $\sqrt{ }$ & $\sqrt{ }$ & & & & \\
6 & $\sqrt{ }$ & $\sqrt{ }$ & $\sqrt{ }$ & $\sqrt{ }$ & & & $\sqrt{ }$ & $\sqrt{ }$ & $\sqrt{ }$ & $\sqrt{ }$ \\
7 & $\sqrt{ }$ & $\sqrt{ }$ & $\sqrt{ }$ & $\sqrt{ }$ & & & $\sqrt{ }$ & $\sqrt{ }$ & $\sqrt{ }$ & \\
8 & $\sqrt{ }$ & $\sqrt{ }$ & $\sqrt{ }$ & $\sqrt{ }$ & & & $\sqrt{ }$ & $\sqrt{ }$ & & \\
9 & $\sqrt{ }$ & $\sqrt{ }$ & $\sqrt{ }$ & $\sqrt{ }$ & & & $\sqrt{ }$ & & & \\
10 & $\sqrt{ }$ & $\sqrt{ }$ & $\sqrt{ }$ & & & & & $\sqrt{ }$ & $\sqrt{ }$ & $\sqrt{ }$ \\
11 & $\sqrt{ }$ & $\sqrt{ }$ & $\sqrt{ }$ & & & & & $\sqrt{ }$ & $\sqrt{ }$ & \\
12 & $\sqrt{ }$ & $\sqrt{ }$ & $\sqrt{ }$ & & & & & $\sqrt{ }$ & & \\
13 & $\sqrt{ }$ & $\sqrt{ }$ & & & & & & & $\sqrt{ }$ & $\sqrt{ }$ \\
14 & $\sqrt{ }$ & $\sqrt{ }$ & & & & & & & $\sqrt{ }$ & \\
15 & $\sqrt{ }$ & & & & & & & & & $\sqrt{ }$ \\
\hline
\end{tabular}

have to ensure that the installed capacity of the PV system is not too high to prevent exporting the excess limit. However, if that happens, the bill will be zero and the excess energy will be credited to the next billing statement and can be kept for up to 24 months for NEM 2.0. Using this concept, the average export rate is always higher than or equal to the import rate.

\subsection{NEM 2.0 scheme}

From the collected data that is under the NEM 2.0 scheme, the important economic parameters were analysed using this scheme before comparing it with NEM 1.0 and 3.0. From eqns $(1)$ and (2), the load energy consumption, $E_{\text {load }}$ from different components, $E_{p v, \text { selco }}$ and $E_{\text {import }}$ can be seen in Fig. 2. From the figure, the PV fraction contributes to 23-34\% of the total load depending on the availability of solar irradiance and electricity usage.

The electricity utility provides the import and export bills and also Bill ${ }_{\text {afterNEM. Since }}$ Bill $_{\text {beforeNEM }}$ has been calculated in the previous section, then, all the bills are depicted in Fig. 3. Referring to Figs. 2 and 3, it can be seen that the Bill ${ }_{\text {beforeNEM }}$ and the import bill are highly dependent on the load consumption. However, the export bill depends on the availability of PV production and the load demand.

The annual data collection and computed parameters can be summarised in Table 7. From the table, the annual Bill ${ }_{\text {beforeNEM }}$ was reduced to RM 2,270 for Bill ${ }_{a f t e r N E M}$, approximately a $66 \%$ reduction. This reduction can be considered as an annual savings benefit from NEM 2.0, which was calculated from eqn (5). From this savings, the PV producer normally calculates the simple payback period in eqn (6), and in this case, the value is 6 years.

However, the annual saving in Table 7 is not considered as net savings because it does not include all the costs that must be spent during the project's lifetime, especially the 


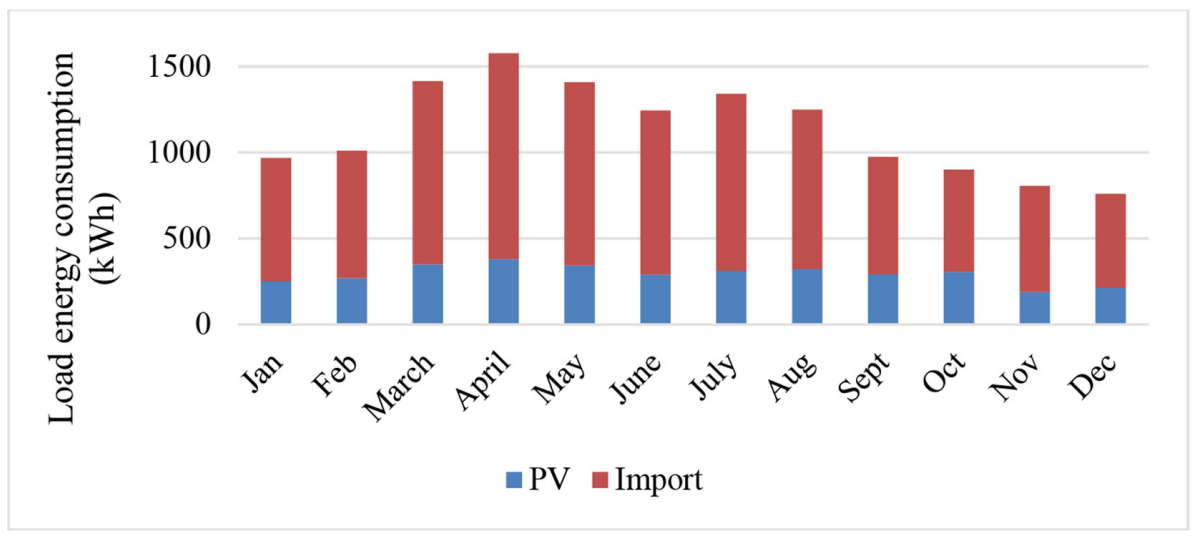

Figure 2: Fraction of energy used by the load.

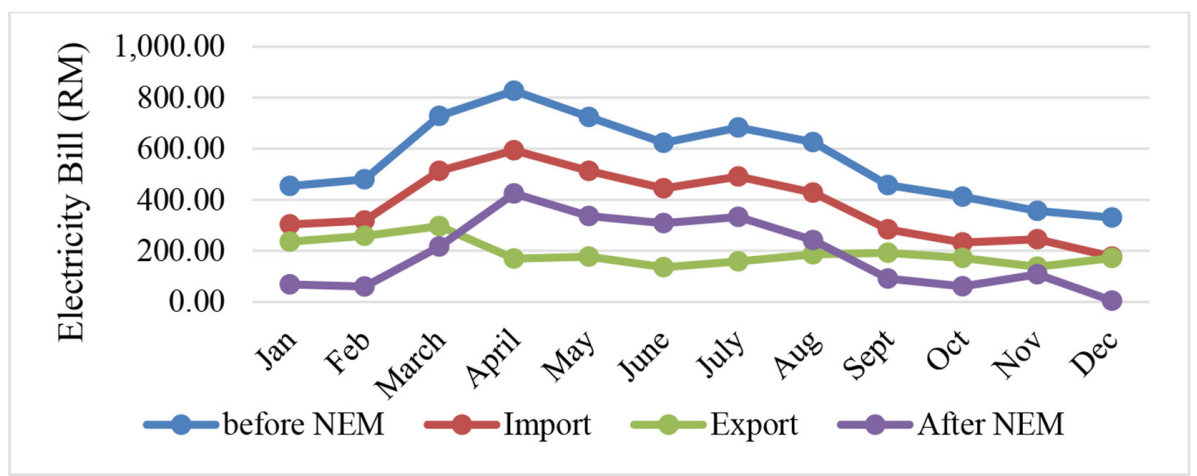

Figure 3: Electricity bill before and after NEM, import and export bills.

replacement cost of the inverter, which has a shorter lifespan. Thus, NPC was calculated as shown in Table 8. Assuming that the inverter is replaced after 10 years, and all the data collection is maintained every year, then the $N P C_{\text {afterNEM }}$ for 20 years can be calculated and the value would be RM 79,392. Note that the $\mathrm{O} \& \mathrm{M}$ cost refers to the Bill $_{\text {afterNEM }}$ for 20 years that must be spent on imported energy from the grid.

The advantage of NEM can be seen clearly from the annual net saving using eqn (9), with a value of RM 2,731. The COE after NEM is also reduced to RM 0.22 per $\mathrm{kWh}$, which shows that the cost of electricity is cheaper by integrating the PV system and the grid.

\subsection{Comparison between NEM 1.0, NEM 2.0 and 3.0}

Using the same collected $E_{P V}, E_{\text {export }}$ and $E_{\text {import }}$, this section compares the performance of the three NEM schemes to see the effect of the parameters when changes are applied to policies, assuming that all parameters remain the same for different schemes. The first parameter is the simple payback period. It can be seen clearly in Fig. 4 that NEM 1.0 has a higher simple 
Table 7: Annual data collection from NEM 2.0 users in the year 2020.

\begin{tabular}{|c|c|}
\hline Parameters & Values \\
\hline Annual $E_{P V}$ & 7,913 kWh \\
\hline Annual $E_{\text {import }}$ & $10,132 \mathrm{kWh}$ \\
\hline Annual $E_{\text {export }}$ & $4,391 \mathrm{kWh}$ \\
\hline Annual $E_{p v \text { selco }}$ & $3,522 \mathrm{kWh}$ \\
\hline Annual $E_{\text {load }}$ & $13,654 \mathrm{kWh}$ \\
\hline Annual Bill $l_{\text {beforeNEM }}$ & RM 6,701.00 \\
\hline Annual import bill & RM 4,405 \\
\hline Annual export bill & RM 2,305 \\
\hline Annual Bill ${ }_{\text {afterNEM }}$ & RM 2,270 \\
\hline Annual saving bill & RM 4,431 \\
\hline
\end{tabular}

Table 8: The $N P C_{\text {afterNEM }}$ components.

\begin{tabular}{lllll}
\hline Component & PV & Inverter & Grid & System \\
\hline Capital (RM) & 19,192 & 7,400 & 0 & 26,592 \\
Replacement (RM) & 0 & 7,400 & 0 & 7,400 \\
O \& M (RM) & 0 & 0 & 45,400 & 45,400 \\
Salvage (RM) & 0 & 0 & 0.00 & 0.00 \\
Total (RM) & 19,192 & 14,800 & 45,400 & 79,392 \\
\hline
\end{tabular}

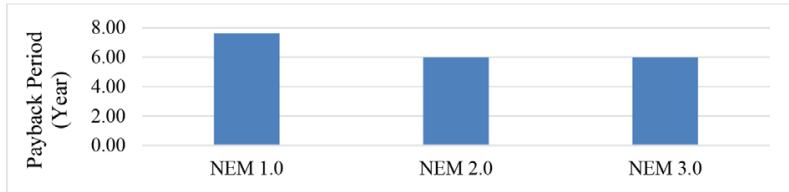

Figure 4: Simple payback period for different NEM schemes.

payback due to the lower export rate, which is fixed at RM 0.31 . Hence, using the same amount of annual export energy as in Table 7, the annual export bill is RM 1,361. Therefore, the reduced annual bill for NEM 1.0 is RM 3,214. The increase in the Bill ${ }_{\text {afterNEM }}$ reduced the annual savings from RM 3,487, thus increasing the payback period to 7.63 years. Meanwhile, for the first 10 years of NEM 3.0, everything would be the same as in NEM 2.0. Accordingly, the simple payback period is similar to that of NEM 2.0.

The NPC value, which was calculated over the project's lifetime of 20 years, was plotted in Fig. 5. For NEM 1.0, the capital and replacement costs are the same as in NEM 2.0. However, the $\mathrm{O} \& \mathrm{M}$ cost, which refers to the electricity bill paid by the consumers, was higher at RM 64,280 for NEM 1.0 compared to that of NEM 2.0, thus the NPC is higher. For NEM 3.0, for the first 10 years, every cost is similar to NEM 2.0. Nonetheless, for the next 10 years, the 


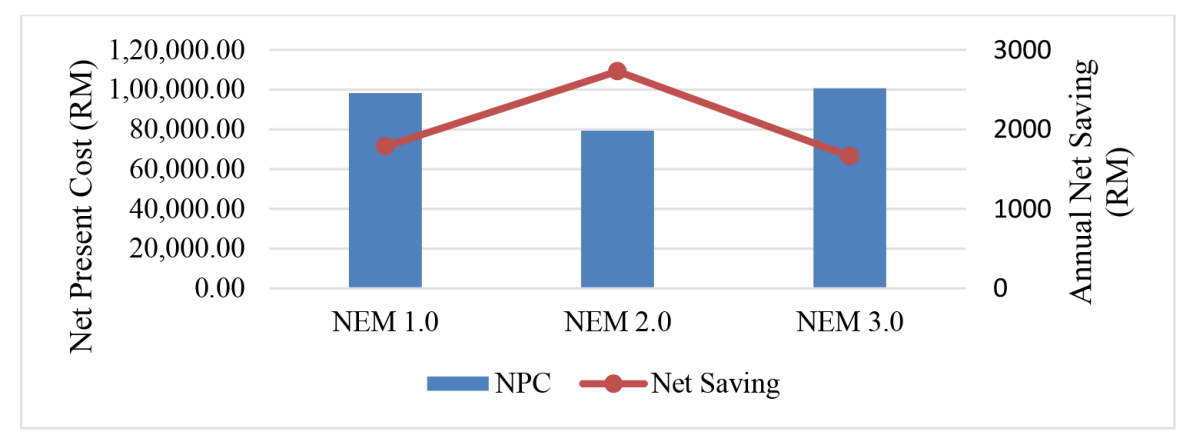

Figure 5: NPC and annual net saving for different NEM schemes.

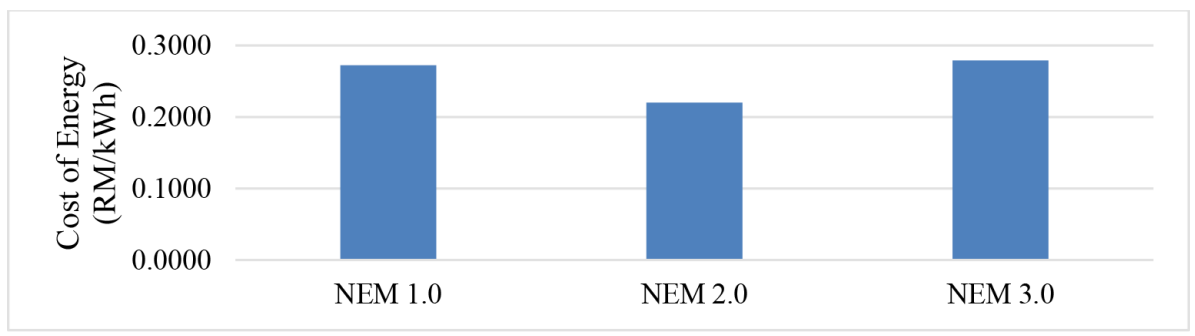

Figure 6: $C O E$ parameters for different NEM schemes.

system cannot export excess electricity into the grid. Thus, the consumer will have to pay the import bill. Using the import bill in Table 7, the O \& M cost can be calculated for NEM 3.0 by adding the reduced bill for 10 years at about RM 22,700 and the import bill for another 10 years at RM 44,050, which produces the highest $N P C$ of RM 100,742. From the $N P C$, the annual net savings can be obtained, and it is expected to have the highest savings from the lowest NPC. The annual net savings from NEM 1.0 and 3.0 are RM 1,787 and RM 1,664, respectively.

Since the $C O E$ value is also closely related to the $N P C$, the higher $C O E$ values in NEM 1.0 and 3.0 are expected, as shown in Fig. 6, with values of $0.2723 \mathrm{RM} / \mathrm{kWh}$ and $0.2792 \mathrm{RM} /$ $\mathrm{kWh}$, respectively. From the COE values, the NEM 3.0 still produces cheaper energy compared to the grid-only system.

\section{CONCLUSION}

This paper investigated the economic parameters of three different schemes of NEM implemented in Malaysia. The results showed that NEM 2.0 provides more benefits to the consumer compared to NEM 1.0 and 3.0 in terms of payback period, NPC, net savings and cost of energy. However, comparing the NEM schemes to the grid-only system, all schemes are capable of reducing electricity bills and generating acceptable annual net savings. This saving is greater if the lifetime of the inverter is longer. In addition, the actual bill calculation has also been explained to clarify misunderstandings with regard to NEM bills. 


\section{ACKNOWLEDGEMENTS}

This research was supported by the Ministry of Higher Education Malaysia, through the Fundamental Research Grant Scheme (Ref: FRGS/1/2018/TK07/UMT/02/1). The authors would like to express their gratitude to the Faculty of Ocean Engineering Technology and Informatics, Universiti Malaysia Terengganu, for providing the facilities during the course of the research.

\section{REFERENCES}

[1] Blank, L. \& Gegax, D., Do residential net metering customers pay their fair share of electricity costs? Evidence from New Mexico utilities. Utilities Policy, 61, p. 100973, September, 2019. https://doi.org/10.1016/j.jup.2019.100973

[2] Razali, A.H., Abdullah, M.P., Hassan, M.Y., Said, D.M. \& Hussin, F., Integration of time of use (TOU) tariff in net energy metering (NEM) scheme for electricity customers. Indonesian Journal of Electrical Engineering \& Informatics, 7(2), pp. 255-262, 2019. https://doi.org/10.11591/ijeei.v7i2.1173

[3] Razali, A.H., Abdullah, M.P., Mat Said, D. \& Hassan, M.Y., Annualized electricity cost of residential solar PV system under Malaysia's NEM scheme. Elektrika - Journal of Electrical Engineering, 19(1), pp. 50-54, 2020. https://doi.org/10.11113/elektrika. v19n1.204

[4] Desa, M.K.B.M., Masri, S. \& Ganesan, L., An economic analysis for grid connected residential photovoltaic system in Malaysia. Int. Conf. on High Voltage Engineering \& Power Systems ICHVEPS 2017 - Proceeding, pp. 145-148, 2017. https://doi. org/10.1109/ICHVEPS.2017.8225931

[5] Mansur, T.M.N.T., Baharudin, N.H. \& Ali, R., Technical and economic analysis of net energy metering for residential house. Indonesian Journal of Electrical Engineering \& Computer Science, 11(2), pp. 585-592, 2018. https://doi.org/10.11591/ijeecs.v11. i2.pp585-592

[6] “SEDA PORTAL.” https://www3.seda.gov.my/. Accessed 03 March 2021.

[7] Razali, A.H., Abdullah, M.P., Hassan, M.Y. \& Hussin, F., Comparison of new and previous net energy metering (NEM) scheme in Malaysia. Elektrika - Journal of Electrical Engineering, 18(1), pp. 36-42, 2019. https://doi.org/10.11113/elektrika.v18n1.141

[8] "Net Energy Metering (NEM) - FAQ - NEM Solar Malaysia." http://nemsolarmalaysia. com/nem-faq-solar-malaysia/. Accessed 03 March, 2021.

[9] Allouhi, A., Saadani, R., Kousksou, T., Saidur, R., Jamil, A. \& Rahmoune, M., Gridconnected PV systems installed on institutional buildings: Technology comparison, energy analysis and economic performance. Energy \& Buildings, 130, pp. 188-201, 2016. https://doi.org/10.1016/j.enbuild.2016.08.054

[10] Li, H.X., Zhang, Y., Li, Y., Huang, J., Costin, G. \& Zhang, P., Exploring payback-year based feed-in tariff mechanisms in Australia. Energy Policy, 150, 112133, 2021. https:// doi.org/10.1016/j.enpol.2021.112133

[11] Bhattacharjee, S. \& Dey, A., Techno-economic performance evaluation of grid integrated PV-biomass hybrid power generation for rice mill. Sustainable Energy Technologies \& Assessments, 7, pp. 6-16, 2014. https://doi.org/10.1016/j.seta.2014.02.005

[12] Islam, M.S., A techno-economic feasibility analysis of hybrid renewable energy supply options for a grid-connected large office building in southeastern part of France. Sustainable Cities \& Society, 38, pp. 492-508, 2018, https://doi.org/10.1016/j.scs.2018.01.022 
[13] Taghavifar, H. \& Zomorodian, Z.S., Techno-economic viability of on grid micro-hybrid $\mathrm{PV} /$ wind/Gen system for an educational building in Iran. Renewable \& Sustainable Energy Reviews, 143, p. 110877, 2021. https://doi.org/10.1016/j.rser.2021.110877

[14] Garriga, S.M., Dabbagh, M. \& Krarti, M., Optimal carbon-neutral retrofit of residential communities in Barcelona, Spain. Energy \& Buildings, 208, 2020. https://doi. org/10.1016/j.enbuild.2019.109651

[15] Maammeur, H., Hamidat, A., Loukarfi, L., Missoum, M., Abdeladim, K. \& Nacer, T., Performance investigation of grid-connected PV systems for family farms: Case study of North-West of Algeria. Renewable \& Sustainable Energy Reviews, 78, pp. 12081220, 2017. https://doi.org/10.1016/j.rser.2017.05.004

[16] Mukisa, N., Zamora, R. \& Tjing Lie, T., Store-on grid scheme model for grid-tied solar photovoltaic systems for industrial sector application: Costs analysis. Sustainable Energy Technologies \& Assessments, 41, p. 100797, 2020. https://doi.org/10.1016/j. seta.2020.100797

[17] S. E. D. A. M. SEDA, "Annual Report 2013,” 2013.

[18] S. E. D. A. M. SEDA, "SEDA Annual Report 2017,” 2017. [Online]. Available: http:// www.seda.gov.my/download/seda-annual-report/

[19] "Pricing \& Tariffs - Tenaga Nasional Berhad." https://www.tnb.com.my/residential/ pricing-tariffs/ (accessed 08 August, 2021).

[20] S. E. D. A. M. SEDA, "SEDA Annual Report 2018," 2018. [Online]. Available: http:// www.seda.gov.my/download/seda-annual-report/ 